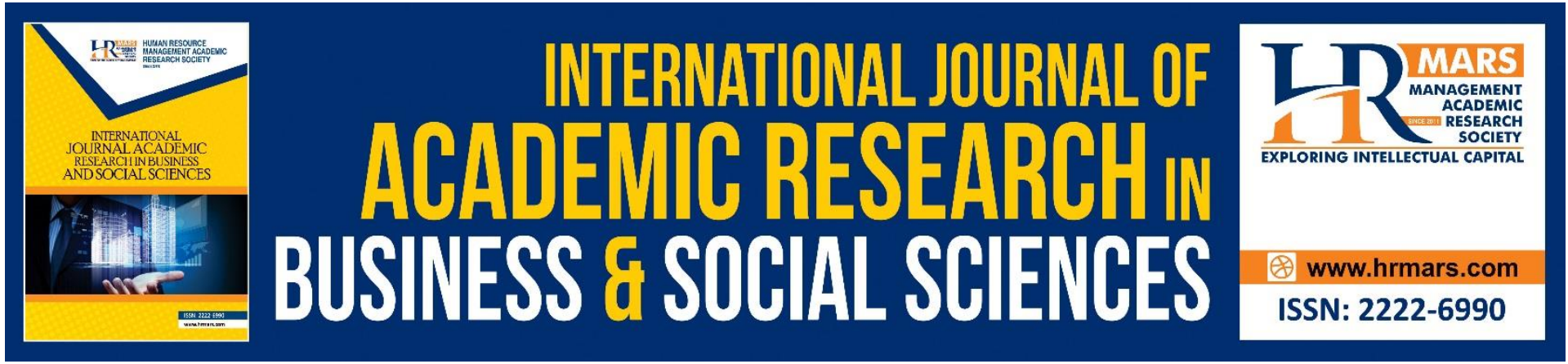

\title{
Organizational Citizenship Behaviour, Self-Efficacy and Academic Motivation as Determinants of Academic Achievement
}

Shaiful Annuar Khalid, Norshimah Abdul Rahman, Norizul Azida Darus, Shafiq Shahruddin, Noraini Nasirun

To Link this Article: http://dx.doi.org/10.6007/IJARBSS/v11-i8/10128

DOI:10.6007/IJARBSS/v11-i8/10128

Received: 07 June 2021, Revised: 12 July 2021, Accepted: 29 July 2021

Published Online: 16 August 2021

In-Text Citation: (Khalid et al., 2021)

To Cite this Article: Khalid, S. A., Rahman, N. A., Darus, N. A., Shahruddin, S., \& Nasirun, N. (2021).

Organizational Citizenship Behaviour, Self-Efficacy and Academic Motivation as Determinants of Academic Achievement. International Journal of Academic Research in Business and Social Sciences, 11(8), 687-705.

Copyright: (c) 2021 The Author(s)

Published by Human Resource Management Academic Research Society (www.hrmars.com)

This article is published under the Creative Commons Attribution (CC BY 4.0) license. Anyone may reproduce, distribute, translate and create derivative works of this article (for both commercial and non-commercial purposes), subject to full attribution to the original publication and authors. The full terms of this license may be seen at: http://creativecommons.org/licences/by/4.0/legalcode

Vol. 11, No. 8, 2021, Pg. 687 - 705

Full Terms \& Conditions of access and use can be found at http://hrmars.com/index.php/pages/detail/publication-ethics 


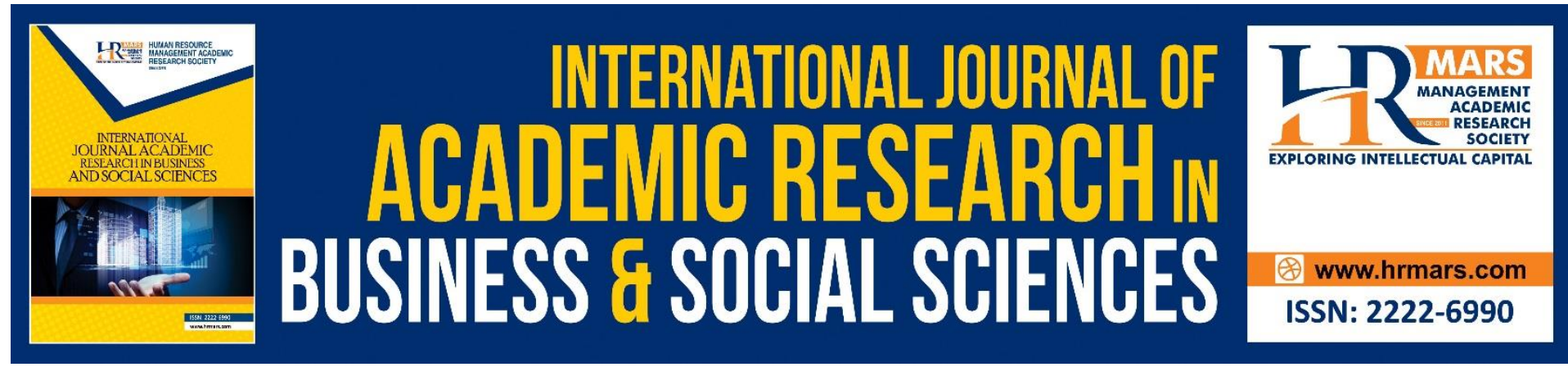

\title{
Organizational Citizenship Behaviour, Self- Efficacy and Academic Motivation as Determinants of Academic Achievement
}

\author{
Shaiful Annuar Khalid ${ }^{1}$, Norshimah Abdul Rahman², Norizul \\ Azida Darus ${ }^{3}$, Shafiq Shahruddin ${ }^{1}$, Noraini Nasirun ${ }^{1}$ \\ ${ }^{1}$ Faculty of Business and Management, Universiti Teknologi MARA Perlis Branch, Malaysia, \\ ${ }^{2}$ Faculty of Accountancy, Universiti Teknologi MARA Perlis Branch, Malaysia, ${ }^{3}$ Academy of \\ Language Studies, Universiti Teknologi MARA Perlis Branch, Malaysia \\ Email: shaiful@uitm.edu.my, shimah70@uitm.edu.my,norizulazida@uitm.edu.my, \\ shafiqshahruddin@uitm.edu.my,noraini305@uitm.edu.my
}

\begin{abstract}
Studies related to academic performance are important to find methods to improve academic achievement at school or higher education. Although studies to examine the factors that contribute to academic performance are increasing, related literature shows that fewer studies have investigated the effects of lecturers' and students' organizational citizenship behavior (OCB) on academic performance as indicated by grade point average (GPA). This study aims to examine the extent to which self-efficacy, motivation, lecturers' OCB and students' OCB can contribute to the academic achievement of higher education students. This study is cross-sectional and descriptive in nature. The sample of this study consists of 312 undergraduates in one of the branches of public universities in the northern region of peninsular Malaysia. Respondents were selected using a convenience sampling method. Hierarchical multiple regression found that students' $O C B$, self-efficacy and intrinsic motivation had a significant positive relationship with GPA. However, lecturers' OCB was not a significant predictor of GPA. The findings of this study have the potential to be used in efforts to improve academic performance. It is suggested that future research should continue to explore the role of lecturers' and students' OCB in enhancing the academic performance.
\end{abstract}

Keywords: Organizational Citizenship Behaviour, Grade Point Average, Self-Efficacy, Motivation

\section{Introduction}

The young generation, especially those who study in higher education institutions, is one of the most important groups of citizens for the future development of a nation. In higher education institutions, students are developed holistically, in terms of academic, character and noble values. Higher learning institutions are introducing different strategies to transform higher education, to run the best governance and efficient delivery system, producing talented graduates who are comprehensive, balanced and entrepreneurial. Administrators and educators engage directly in ensuring that students also master the academic curriculum 
and aspire to achieve excellence in the academic field. The academic achievement as well as ownership of the skills and values learned would enable students to be more competitive. In Malaysia, academic achievement is very important to determine the direction of a student whether to further their studies or for the purpose of applying for a job either in the public or private sector. Factors that contribute to student success have been examined worldwide, including the role of the government, the leadership of higher learning institutions, the positions of lecturers, and the students themselves. One of the fields of academic performance research focuses on the role of the organizational citizenship behaviors of educators. In their OCB review of literature, Podsakoff, MacKenzie and Paine (2000) reported the potential of $O C B$ for enhancing the performance of individuals, groups and organizations. However, limited studies have examined the relationship between OCBs and the performance of school and university students (Allison, Voss \& Dryer, 2001; DiPaola \& Hoy, 2002). These limited studies have taken two different approaches which were the relationship between educators' OCB and academic performance or between students' OCB and academic performance, either at the organizational level (schools) or individual levels (students).

Studies by DiPaola and Hoy (2005); Khalid, et al (2010) have examined the relationship between educators' OCB and students' academic performance. On the other hand, Allison et al., (2001), is the only research that has studied the relationship between the OCB of students and academic success. To our knowledge, there have been no studies other than Allison et al (2001) conducted to add support that a student's OCB also contributes to their own academic performance, apart from educators' OCBs. Therefore, it is necessary to continue investigating the relationship between students' OCBs and performance so that with more evidence, actions can be planned and carried out to inculcate OCBs among students. Ongoing research is needed to find practical strategies towards improving academic performance at the primary, secondary and tertiary levels.

This study was conducted to answer the following research questions.

Research question 1 - Whether there is a significant relationship between lecturers' OCB and academic achievement?

Research question 2 - Whether there is a significant relationship between dimensions of students' OCB and academic achievement?

Research question 3 - Is there a significant relationship between self-efficacy and academic achievement?

Research question 4 - Is motivation (intrinsic and extrinsic) related to academic achievement? The findings of this study will enable actions to be designed and implemented to strengthen the practice of OCBs among educators and students that will certainly bring benefits to institutions of higher learning.

\section{Literature}

\section{Academic Achievement}

One of the hallmarks of an educational institution's effectiveness is the performance of students in academia, as well as the growth of certain skills and abilities, such as communication, decision-making, leadership, etc. It is an integrative contribution by the students themselves and with the aid of educators and all kinds of learning facilities offered in the sense of academic performance. In general, a person's success is measured in various ways such as the success of getting a job, self-development as well as the success of getting a 
degree (Schroeder, 2011). Perna and Thomas (2008) stated that there are 3 indicators of student success in the literature, success in entering tertiary education, academic achievement throughout studies and the strength as well as resilience to graduate. Today, higher education students have different characteristics in terms of educational background, social status, academic potential and skills. With the increase in student diversity, effort in determining potential factors that enhance academic performance of higher education students is also one of the important agendas (Danilowicz-Gosele, Lerche, Meya \& Schwager, 2017). Apart from the impact of OCB on academic performance, previous studies have identified several other factors that also contribute to academic success. There are learning habits among students, support for the learning process in the classroom, family support (Perger \& Takacs, 2016), leaning motivation (Hsieh, 2014), socioeconomic status and selfconcept (Li, Xu \& Xia, 2020), students' prior academic achievement (Robert, 2013), approaches to learning (Angus, 2004), demographic factors (Hong, 1984), self-efficacy and achievement motivation (Robbins, Lauver, Davis, Langley \& Carlstrom, 2004) among others. Most of the studies related to academic performance are widely published in journals related to education and psychology. The methods used to study academic performance are mostly quantitative (Perger \& Takacs, 2016).

\section{Organizational Citizenship Behavior}

OCB is characterized as discretionary workers' behaviors, not acknowledged specifically or indirectly by the prescribed compensation scheme, which in the aggregate contributes to effective functioning of the organization (Organ, 1988). The word discretionary suggests that OCB is an employee action of choice, and failure to follow OCB does not normally lead to disciplinary actions. It is generally accepted, however, that the organization expects staff to contribute beyond what is indicated in the job description. Among such behaviors are helping colleagues complete an important job-related task, resisting complaining about any deficiencies in the office, engaging in organizational development, such as being a member of several committees, active in channeling views constructively for the benefit of the department and organization, willingly shorten rest time in order to complete an assignment or helping clients and always maintain good relationships with colleagues and supervisors. Although in the early stages, the OCB studies focused more on determining factors contributing to $O C B$, the study also began to examine the effects of $O C B$, such as the impact of OCB on job performance and performance assessment. The impact of OCBs on performance have been studied both at the level of individual (Allen \& Rush, 1998; Chen et al. 1998; Khalid et al. 2010) as well as organizational (Podsakoff, Ahearne \& Mackenzie, 1997). The results of the studies that OCBs contribute to performance are capable of offering both researchers and practitioners confidence of the benefit of $O C B$. This is because, preliminary studies relating to factors that contribute to OCB were carried out on the basis of the assumption that OCBs contributes to performance. Several dimensions of OCB have been studied by researchers. Among them are Williams and Anderson (1988), who indicated that OCB has two dimensions that benefit both the organization (OCBO) and individual (OCBI). DiPaola and Tschannen-Moran (2001) who were among the first researchers to study OCB in the context of school, found that OCB is a uni-dimensional construct. Organ (1990) suggested that $O C B$ is a 5-dimensional construct, namely altruism, courtesy, athletics, civic virtue, and conscientiousness. The five main aspects of the $O C B$, namely altruism, civic virtue, conscientiousness, courtesy and civic virtue, were discussed by Organ (1990). The meaning of each dimension is provided in Table 1. 
Table 1

\section{Descriptions of OCB Dimensions}

\begin{tabular}{|c|c|c|}
\hline OCB Dimension & Meaning & Source \\
\hline Altruism & $\begin{array}{l}\text { Actions taken voluntarily to } \\
\text { help others such as } \\
\text { colleagues to complete } \\
\text { work-related tasks }\end{array}$ & $\begin{array}{l}\text { Podsakoff \& MacKenzie } \\
1994\end{array}$ \\
\hline Civic virtue & $\begin{array}{l}\text { Active participation in the } \\
\text { development of the } \\
\text { organization as well as } \\
\text { being very concerned with } \\
\text { the life of the organization }\end{array}$ & $\begin{array}{l}\text { Podsakoff \& MacKenzie } \\
\text { (1994) }\end{array}$ \\
\hline Conscientiousness & $\begin{array}{l}\text { The use of working time, } \\
\text { attendance and compliance } \\
\text { with all forms of } \\
\text { organizational rules exceeds } \\
\text { the minimum standards }\end{array}$ & Organ (1990) \\
\hline Courtesy & $\begin{array}{l}\text { Actions taken to avoid work- } \\
\text { related conflicts with other } \\
\text { parties, such as managers } \\
\text { and superiors }\end{array}$ & $\begin{array}{l}\text { Podsakoff \& MacKenzie } \\
\text { (1994) }\end{array}$ \\
\hline Sportsmanship & $\begin{array}{l}\text { Ability and willingness to } \\
\text { tolerate any discomfort or } \\
\text { difficulty in the workplace } \\
\text { and perform tasks without } \\
\text { complaining }\end{array}$ & Organ (1990) \\
\hline
\end{tabular}

\section{Lecturers' OCB and Academic Performance}

Higher education lecturers are directly involved in the implementation of their respective universities' curriculum and educational programs. The role played by lecturers is very important, especially in terms of achieving student and university aspirations and goals of excellence. Lecturers directly and actively involved in research and publishing and be prepared to holistically train students. They must be willing to perform the duties and responsibilities assigned to educate students as future generations. The role of higher education educators is demanding. The teaching role is demanding and complex since it requires constant contact between lecturers and students from different backgrounds. Lecturers are also expected to be active in research and publication, community and university programs and leadership. Teaching involves educating and imparting information that cannot be fully outlined in the job description of the lecturers (Mazen, Herman \& Ornstein, 2008). The capacity of lecturers to demonstrate high levels of OCBs may have a positive impact on the outcomes of student learning. Educators are close to the students and thus play a big role in influencing the success of the students. The role of educators in determining the success of students is largely played by their behaviors to help and facilitate the learning process of students. Behaviors such as allocating more time than the official schedule to give guidance, assist new lecturers in the teaching process, give advice and views for the success of students, give words of encouragement and motivation to students, rarely 
involved with absenteeism unless absolutely necessary, using time productively as well as making full use of the talents they possess to help students (DiPaola \& Hoy, 2005). In comparison, more evidence is available in supporting the relationship between educators' OCB and students' performance, than the relationship between students' OCB and academic performance. Studies by DiPaola and Hoy (2005); Khalid et al (2010) as well as Burns and DiPaola (2013) show that OCB practices among educators are able to have a positive impact at academic performance. Behaviors of educators such as using more time or coming home late to help students understand the subjects taught, holding extra classes and being ready to help students are among the citizenship behaviors that can help students to achieve success.

From a theoretical perspective, social exchange theory describes the formation of relationships among individuals from the point of view of reciprocal resources that are considered valuable among the individuals involved. This theory is useful for explaining and understanding the relationships that exist within the organization (Gouldner, 1960). The hard work on the part of educators in the process of educating students, which is shown through a high level of $O C B$, should be considered something that students appreciate. In return, it is appropriate for the students to study diligently in order to achieve better exam results, which will make their teachers proud.

\section{Students' OCB and Academic Performance}

The theory of cognitive dissonance suggests that individual have an internal drive to harmonize attitudes and behavior and prevent disharmony (or dissonance). This is known as the cognitive consistency principle (Festinger, 1957). In the context of this study, a student with a high level of OCB is a student who easily helps friends to understand difficult subjects, respects friends and lecturers, is responsible for time management, is willing to work hard in the search for knowledge, and so on. Based on this theory, it is possible to state that students with high OCB levels also form positive attitude and behavior in their studies by trying to achieve academic success. High level of students' OCB is consistent with high academic achievement. 


\section{Table 2}

\section{Comparison of Studies on OCB and Academic Achievement}

\begin{tabular}{|c|c|c|c|}
\hline Study/Sample & Measurements & Analysis & Findings \\
\hline $\begin{array}{l}\text { - } \text { Allison et al., } \\
\text { (2001) } \\
\text { - Individual unit } \\
\text { of analysis } 222 \\
\text { USA under- } \\
\text { graduates }\end{array}$ & $\begin{array}{l}\text { - Students' OCBs - } \\
17 \text { items from } \\
\text { Podsakoff and } \\
\text { MacKenzie } \\
\text { (1994) and } \\
\text { MacKenzie et al., } \\
\text { (1993). } \\
\text { - Academic } \\
\text { Performance - } \\
\text { productivity } \\
\text { (course load } \\
\text { measured in } \\
\text { credit hours) and } \\
\text { CGPA }\end{array}$ & $\begin{array}{l}\text { - } \text { Regression } \\
\text { - } \text { Control for } \\
\text { social } \\
\text { desirability }\end{array}$ & $\begin{array}{l}\text { - A global measure of } \\
\text { OCB was associated } \\
\text { significantly with } \\
\text { productivity } \\
\text { ( } \beta=.24 ; p=.001 \text { ) and } \\
\text { CGPA ( } \beta=.21 ; p=.004) \text {. } \\
\text { OCB dimensions of } \\
\text { sportsmanship ( } \beta=.19 ; \\
\text { p=.008), } \\
\text { conscientiousness } \\
\text { ( } \beta=.25 ; p=.001) \text { and } \\
\text { civic virtue ( } \beta=.17 ; \\
\text { p=.020) significantly } \\
\text { predicted } \\
\text { productivity, while } \\
\text { sportsmanship ( } \beta=.16 ; \\
\text { p=.028) and } \\
\text { conscientiousness } \\
\text { ( } \beta=.29 ; p=.000) \\
\text { significantly predicted } \\
\text { CGPA }\end{array}$ \\
\hline $\begin{array}{l}\text { - DiPaola and } \\
\text { Hoy (2005) } \\
\text { - Organizational } \\
\text { level - } 97 \text { high } \\
\text { school in USA }\end{array}$ & $\begin{array}{l}\text { - OCB in School } \\
\text { Scales (OCBSS) - } \\
15 \text { Likert items } \\
\text { (aggregate the } \\
\text { scores of } \\
\text { teachers' OCB) } \\
\text { - School } \\
\text { performance - } \\
\text { mathematics and } \\
\text { reading } \\
\text { (measured by the } \\
\text { Ohio Department } \\
\text { of Education) }\end{array}$ & $\begin{array}{l}\text { - Regression } \\
\text { - Control } \\
\text { for SES }\end{array}$ & $\begin{array}{l}\text { OCBSS significantly } \\
\text { predicted reading } \\
(\beta=.28 ; p<.05) \text { and } \\
\text { mathematics }(\beta=.33 ; \\
p<.05)\end{array}$ \\
\hline $\begin{array}{l}\text { - Khalid et al., } \\
\text { (2010) } \\
\text { - Individual level } \\
-196 \\
\text { undergraduates } \\
\text { in Malaysia }\end{array}$ & $\begin{array}{l}\text { - Lecturers' OCB - } \\
17 \text { items scale by } \\
\text { Podsakoff \& } \\
\text { Mackenzie (1994) } \\
\text { - Academic } \\
\text { achievement - } \\
\text { CGPA } \\
\text { - Moderator } \\
\text { variable - }\end{array}$ & - Regress & $\begin{array}{l}\text { Altruism ( } \beta=.38 ; \\
p<.01) \text { and courtesy } \\
(\beta=.30 ; p<.01) \\
\text { significantly predicted } \\
\text { CGPA } \\
\text { - The interaction } \\
\text { between } \\
\text { conscientiousness and } \\
\text { students' needs for } \\
\text { achievement is also }\end{array}$ \\
\hline
\end{tabular}




\begin{tabular}{|c|c|c|c|}
\hline $\begin{array}{ll}\text { - } & \text { Burns \& } \\
\text { DiPaola } \\
\text { (2013) } \\
\text { - } \quad \text { Organizational } \\
\text { level- } 34 \\
\text { public high } \\
\text { schools }\end{array}$ & $\begin{array}{l}\text { - OCB was } \\
\text { measured using } \\
\text { OCBS (aggregate } \\
\text { the scores of } \\
\text { teachers' OCB) } \\
\text { - Academic } \\
\text { achievement was } \\
\text { measured using } \\
\text { Virginia Standards } \\
\text { of Learning (SOL) } \\
\text { assessment } \\
\text { (degree to which } \\
\text { students have } \\
\text { mastered content } \\
\text { and skills } \\
\text { identified in the } \\
\text { Virginia SOL } \\
\text { Curriculum } \\
\text { Framework }\end{array}$ & $\begin{array}{l}\text { - Regression } \\
\text { - Controlling } \\
\text { for SES }\end{array}$ & $\begin{array}{l}\text { significant. Further } \\
\text { analysis revealed that } \\
\text { relationship between } \\
\text { conscientiousness and } \\
\text { CGPA is stronger } \\
\text { among students with } \\
\text { higher needs for } \\
\text { achievement } \\
\text { OCBS (Composite } \\
\text { measure) } \\
\text { significantly } \\
\text { predicted biology } \\
(\beta=.52 ; p<.01), \\
\text { reading }(\beta=.34 ; \\
p<.05)\end{array}$ \\
\hline
\end{tabular}

The only known study that has examined the relationship between students' OCB and academic performance was by Allison et al., (2001). Using a sample of 222 undergraduates in the USA, their study found a significant relationship between dimensions of OCB students such as sportsmanship and conscientiousness with academic performance indicators, namely productivity and cumulative grade point average (CGPA). Conscientiousness involves behaviors such as focusing on time management, being actively involved in the classroom and the willingness to perform more tasks than they should and eager to engage in learning activities. On the other hand, sportsmanship involves behaviors that reflect the high level of patience that is usually possessed by athletes before achieving success. In the context of a student, sportsmanship involves the behavior of avoiding complaining about deficiencies that occur during the learning process (Allison et al. 2001). It is believed that such behaviors have the potential to contribute to academic performance and are among the characteristics of successful students. Table 2 summarizes studies on OCB and academic achievement.

\section{Academic Motivation and Academic Achievement}

There are many theories related to motivation. This study evaluates academic motivation in the context of self-determination theory by Deci and Ryan (1985). There are three types of motivation suggested by this theory, namely intrinsic, extrinsic and amotivation. Intrinsic motivation is the tendency to engage in a task because the task is seen as interesting and 
enjoyable while involvement with a task due to factors such as expectations of rewards or punishments are associated with extrinsic motivation (Deci \& Ryan, 1985). Past studies have indeed found that a student who has a high level of motivation is able to achieve a better level of academic success. Students with a high degree of academic encouragement in general have a high level of interest in the learning process and achieve higher grade achievement (Sikhwari, 2014). A student who is interested and agrees that a topic is relevant is more attentive and concentrated and leads to better academic achievement (Bruinsma, 2004). Hsieh (2014) notes that, depending on the form of motivation, the effect on students' learning often varies. A student with a high level of extrinsic motivation, for example, reported a high level of learning effort (Roebken, 2007), while intrinsic motivation was reported to have a stronger correlation with academic achievement as well as test results (Vansteenkiste et al., 2004).

\section{Self-Efficacy and Academic Achievement}

One of the variables considered essential in affecting training and learning is self-efficacy. Selfefficacy requires one's confidence in one's own capacity to understand or do something to some degree (Bandura 1997). He added that trusting in one's own capacity to perform a task is a powerful contributor to the accomplishment that results from the task performed. Selfefficacy plays an important part in enhancing academic performance. A student with a high degree of self-efficacy is a student who is able to learn hard, is successful in the learning process, has stamina, is not emotionally distressed when faced with difficulties compared to those who are less confident in their own skills (Zimmerman, 2000). Several studies have verified the association between self-efficacy and academic performance (Choi, 2005; Multon et al., 1991; Zhu et al., 2011).

\section{Methods}

\section{Participants}

This research is correlational and cross-sectional with a quantitative approach (Gravetter \& Forzano, 2009) aimed at achieving the objective of evaluating the effects of self-efficacy, motivation and OCB on academic performance. This study was conducted at one of the branch campuses of the largest public university in Malaysia. The branch campus offers business management studies, as well as science and technology academic programs. The population of this study consists of 6,700 students undergoing bachelor degree and diploma programs. The sample size required is about 362 (Krecjie \& Morgan, 1970).

\section{Procedure}

The process of gathering the data for this research was conducted using Google forms distributed using several classes WhatsApp groups. Due to Movement Control Order (MCO) which limit the ability of researchers' mobility, a convenience systematic sampling technique was used to collect the data (Sekaran \& Baugie, 2010). To ensure that the participants have enough time to answer in a comfortable situation, the respondents were given five days to answer the questionnaire. Clear instructions accompanied these Google form and the contact details of the researcher are also included in the questionnaire form so that the respondents may ask if there are any inquiries about any clarifications that need to be explained more. The objectives of this study have also been clearly stated in the questionnaire. Participation is voluntary and researchers have ensured that confidentiality is fully preserved. Respondents were informed that it took approximately 10 minutes to respond. 


\section{Measurement}

Students' OCB. This variable was measured using a 10-item scale by Allison, Voss and Dryer (2001). The 10-item scale was intended to measure the 5 OCB dimensions - altruism, courtesy, conscientiousness, civic virtue and sportsmanship. It is measured using a 5-point scale from 1 (strongly disagree) to 5 (strongly agree). Sample items include "I willingly give my time to help other students who have study-related problems" and "I take steps to try to prevent problems with other students in my class". For this study, this measurement has an alpha value of 87 .

Lecturers' OCB. This variable was measured using a 12-item scale by DiPaola and Hoy (2004). Sample survey items include "Lecturers help students on their own time" and "Lecturers waste a lot of class time". Since one of the objectives of this study is to examine the extent to which lecturers' OCB contribute to student academic performance, the students are the ones who should assess the level of OCB of their lecturers. Some changes in measurement by DiPaola and Hoy (2004) have been made to enable students to be in a position to provide the best possible feedback of their lecturers' OCBs.

Self-Efficacy. This variable was measured using a 3-item scale from Spreitzer (1995). A sample item is "I am confident about my ability to do my academic tasks".

Learning motivation. This variable was measured using a 7-item scale from Pintrich et al., cited in Hsieh (2014). Sample items are "The most satisfying thing for me in my course is trying to understand the content as thoroughly as possible" and "If I can, I want to get better grades in my course than most of the other students".

Academic Performance. Students' academic performance is measured using Grade Point Average (GPA). GPA is the most frequently used indicator of academic success (York, Gibson \& Rankin, 2015).

\section{Data Analysis}

To answer the research questions, this study uses correlations and hierarchical multiple regression analyses. Standard deviation, mean, median is calculated for the study variables. Hierarchical multiple regression is used to examine the effect of independent variables on the dependent variable. Lecturers' and students' organizational citizenship behaviour, selfefficacy and learning motivation were the independent variables and GPA as a measure of academic achievement was the dependent variable. In the hierarchical multiple regression, Block 1 contains self-efficacy and learning motivation. Block 2 contains lecturers' OCB and Block 3 (full model) contains all variables including the students' OCB. If the variance inflation factor (VIF) for any variable was 10 (or even> 5 to be very conservative), this would imply a problem of multicollinearity (Schroeder, 1990). The VIF value for each variable was below 2.6 in this analysis, indicating that multicollinearity was not serious.

\section{Data Analysis and Findings Sample Characteristics}

Using the convenience sampling method, the Google form survey has been fully used to collect data from students who are directly involved with online learning since March 2020 which stems from the Covid-19 pandemic. Of the total of 747 students who received the Google form survey distributed via several WhatsApp groups, a total of 312 students have responded. The majority of students for this study were females (64.4\%). About $70.8 \%$ of students are pursuing bachelor degree programs, while the rest are diploma-level students. 
The number of students from science and technology $(52.2 \%)$ is approximately equal to the number of students from management science (47.4\%).

\section{Goodness of Measure}

\section{Table 3}

\section{Factor Analysis for Lecturers' OCB Items}

\begin{tabular}{|c|c|c|c|}
\hline No. & Item & & $\begin{array}{c}\text { Component } \\
1\end{array}$ \\
\hline 1 & Lecturers help students on their $\mathrm{o}$ & time & .56 \\
\hline 2 & Lecturers begin online class prom & and use class time effectively & .75 \\
\hline 3 & Lecturers follow the online lecture & tutorials as scheduled & .76 \\
\hline 4 & $\begin{array}{l}\text { Lecturers make innovative sugges } \\
\text { of the university }\end{array}$ & s to improve the overall quality & .75 \\
\hline 5 & Overall, the lecturers are producti & & .81 \\
\hline 6 & $\begin{array}{l}\text { Lecturers inform in advance if the } \\
\text { lecture/tutorial }\end{array}$ & a change in the time of online & .65 \\
\hline 7 & $\begin{array}{l}\text { Throughout the online learning, th } \\
\text { according } \\
\text { to the syllabus and return the mar }\end{array}$ & $\begin{array}{l}\text { ecturers give assignments } \\
\text { assignments. }\end{array}$ & .67 \\
\hline 8 & $\begin{array}{l}\text { Lecturers consult students before } \\
\text { them }\end{array}$ & iating actions that might affect & .78 \\
\hline 9 & Lecturers respond to students' inc & es immediately. & .79 \\
\hline 10 & $\begin{array}{l}\text { Lecturers always motivate studen } \\
\text { online learning. }\end{array}$ & continue to persevere in & .77 \\
\hline 11 & $\begin{array}{l}\text { Through online learning, lecturers } \\
\text { impart knowledge regardless of ti }\end{array}$ & ready to give guidance and & .81 \\
\hline 12 & Lecturers rarely cancel online clas & / tutorials. & .43 \\
\hline 13 & Lecturers use the expertise and ta & s they have to help students. & .76 \\
\hline $\mathrm{KMO}$ & Measure of Sampling Adequacy & .939 & \\
\hline Bartl & ett's Test of Sphericity, Chi-Square & 21.54.914 & \\
\hline & $d f$ & 78 & \\
\hline & Sig. $=$ & .000 & \\
\hline
\end{tabular}

Prior to testing for the relationships between variables, the principle component analysis (PCA) method with varimax rotation (Hair, Anderson, Tatham \& Black, 1998) is used to identify underlying dimensions of lecturers' OCB, students' OCB and learning motivation. PCA is the most frequently used approach (Cooper \& Schindler, 2001). Table 3 illustrates the result of factor analysis for 13 items measuring lecturers' OCB. The 13-item loaded significantly into a single factor. The second factor analysis was conducted on the 10-item scale measuring students' OCB. As shown in Table 4, the 10 items were loaded into 3 factors. Two altruism items, two courtesy items and one conscientiousness item loaded together in factor 1 . This factor was labelled as courtesy / altruism. Factor 2 consists of two civic virtue items and one conscientiousness item and was labelled as civic virtue. The last factor consists of two sportsmanship items. Finally, the seven items intended to measure learning motivation loaded nicely into two factors. As shown in Table 5, the first factor consists of four items 
intended to measure intrinsic motivation and the other three items on extrinsic motivation loaded into the second factor.

\section{Table 4}

\section{Factor Analysis for Students' OCB Items}

\begin{tabular}{|c|c|c|c|c|c|}
\hline \multirow[t]{2}{*}{ No } & \multirow{2}{*}{\multicolumn{2}{|c|}{ Item }} & \multicolumn{3}{|c|}{ Component } \\
\hline & & & 1 & 2 & 3 \\
\hline 1 & \multicolumn{2}{|c|}{$\begin{array}{l}\text { I take steps to try to prevent problems with other students in my } \\
\text { class. }\end{array}$} & .82 & .04 & .16 \\
\hline 2 & \multicolumn{2}{|c|}{$\begin{array}{l}\text { I "touch base" with other students before initiating actions that } \\
\text { might affect them (e.g., in team projects). }\end{array}$} & .79 & .10 & .09 \\
\hline 3 & \multicolumn{2}{|c|}{$\begin{array}{l}\text { I willingly give of my time to help other students who have } \\
\text { faculty/university related problems. }\end{array}$} & .67 & .38 & .09 \\
\hline 4 & \multicolumn{2}{|c|}{$\begin{array}{l}\text { I am willing to take time out of my own busy schedule to helps } \\
\text { students with their homework. }\end{array}$} & .59 & .51 & .17 \\
\hline 5 & \multicolumn{2}{|c|}{$\begin{array}{l}\text { I return phone call calls from students/lecturers and respond to } \\
\text { other messages and requests for information promptly. }\end{array}$} & .56 & .32 & .15 \\
\hline 6 & \multicolumn{2}{|c|}{ I attend and actively participate in faculty / university meetings. } & .17 & .81 & .01 \\
\hline 7 & \multicolumn{2}{|c|}{$\begin{array}{l}\text { I attend special classes or other meetings that students are } \\
\text { encouraged but not required to attend. }\end{array}$} & .11 & .78 & .23 \\
\hline 8 & \multicolumn{2}{|c|}{ I turn in homework, projects, reports, etc. earlier than is required. } & .34 & .47 & .19 \\
\hline 9 & \multicolumn{2}{|c|}{$\begin{array}{l}\text { I always focus on what is wrong with my situation rather than the } \\
\text { positive side of it. }\end{array}$} & .18 & .01 & .89 \\
\hline 10 & \multicolumn{2}{|c|}{ I always find fault with what the faculty/university is doing. } & .06 & .52 & .71 \\
\hline \multicolumn{2}{|c|}{ KMO Measure of Sampling Adequacy } & .793 & & & \\
\hline \multicolumn{2}{|c|}{ Bartlett's Test of Sphericity, Chi-Square } & 933.541 & & & \\
\hline & df & 45 & & & \\
\hline & Sig. & .000 & & & \\
\hline
\end{tabular}




\section{Table 5}

\section{Factor Analysis for Learning Motivation Items}

No Item

Componen

12

1 In my course, I prefer course material that really challenges me so that I

$.74 \quad .09$
can learn new things.

2 In my course, I prefer course material that arouses my curiosity, even if it

$.82 \quad .03$ is difficult to learn.

$\begin{array}{llll}3 & \text { The most satisfying thing for me in my course is trying to understand the } & .62 & .63\end{array}$ content as thoroughly as possible.

$\begin{array}{llll}4 & \text { When I have opportunity, I choose course assignment that I can learn } & \mathbf{7 8} & .02\end{array}$ from, even if they don't guarantee a good grade.

5 Getting a good grade is the most satisfying thing for me. $\quad .09 \quad .82$

$\begin{array}{llll}6 & \text { If I can, I want to get better grades than most of the other students. } & .11 & .86\end{array}$

$\begin{array}{llll}7 & \text { I want to do well because it is important to show my ability to my family, } & .05 & \mathbf{8 2}\end{array}$ friends or others.

KMO Measure of Sampling Adequacy $=\quad .742$

Bartlett's Test of Sphericity, Chi-Square $=593.496$

$\begin{array}{lll}\mathrm{df} & =21 \\ \mathrm{Sig} . & = & .000\end{array}$

Table 6

Reliability Analysis

\begin{tabular}{lcl}
\hline Variable & No. of Item & $\boldsymbol{\alpha}$ \\
\hline Self Efficacy & 3 & .88 \\
Intrinsic motivation & 4 & .74 \\
Extrinsic motivation & 3 & .79 \\
Lecturers' OCB & 13 & .92 \\
Students' Courtesy/Altruism & 5 & .79 \\
Students' Civic virtue & 3 & .71 \\
Students' sportsmanship & 2 & .72 \\
\hline
\end{tabular}

Table 6 indicates the Cronbach's alpha for these dimensions. According to Nunnally (1978) Cronbach alpha should be greater than 0.70. As indicates in Table 3, the alpha values for all variables are above 0.70 . 
Descriptive Statistics and Inter-Correlations

Table 7

Descriptive Statistics of Mean and Standard Deviation

\begin{tabular}{cccc}
\hline Variable & Mean & SD & Range \\
\hline Grade Point Average & 3.48 & .30 & 1.71 \\
Self-Efficacy & 3.78 & .68 & 3 \\
Intrinsic motivation & 3.83 & .59 & 4 \\
Extrinsic motivation & 4.42 & .69 & 3 \\
Lecturers' OCB & 4.30 & .51 & 2 \\
Students' Courtesy/Altruism & 4.06 & .54 & 3 \\
Students' civic virtue & 3.55 & .76 & 4 \\
Students' sportsmanship & 3.16 & .96 & 4 \\
\hline
\end{tabular}

Table 7 shows the means, standard deviations, and ranges of all measures in this study. All the constructs were measured based on the 5-point Likert scale. As can be seen, all the mean values for constructs were above the mid-point of three, with the highest of 4.42 for extrinsic motivation and the lowest of 3.16 for students' sportsmanship. In general, the values of standard deviations for most constructs indicated that the observations were rather closed to the mean.

\section{Table 8}

Correlational Analysis

\begin{tabular}{lccccccccc}
\hline & & 1 & 2 & 3 & 4 & 5 & 6 & 7 & 8 \\
\hline 1. & GPA & - & & & & & & & \\
2. & SE & $.14^{*}$ & - & & & & & & \\
3. & IM & $.13^{*}$ & $.48^{* *}$ & - & & & & & \\
4. & EM & .10 & $.30^{* *}$ & .00 & - & & & & \\
5. & LOCB & .03 & $.42^{* *}$ & $.35^{* *}$ & $.29^{* *}$ & - & & & \\
6. & SCA & $.14^{*}$ & $.39^{* *}$ & $.35^{* *}$ & $.37^{* *}$ & $.52^{* *}$ & - & & \\
7. & SCV & .05 & $.43^{* *}$ & $.23^{* *}$ & .07 & $.16^{* *}$ & .00 & - & \\
8. & SS & $.16^{* *}$ & .01 & $.15^{*}$ & .02 & .02 & .00 & .00 & - \\
\hline
\end{tabular}

${ }^{*} \mathrm{p}<.05 ;{ }^{* *} \mathrm{p}<.01$

GPA : Grade point average; SE : Self efficacy; IM : Intrinsic motivation; EM : Extrinsic motivation; LOCB : Lecturers' OCB; SCA : Students' courtesy / altruism; SCV : Students' civic virtue; SS : Students' sportsmanship.

Intercorrelations are shown in Table 8. GPA has a significant correlation relationship with 4 variables: self-efficacy $(r=.14, p<.05)$, intrinsic motivation $(r=.13, p<.05)$, students 'courtesy / altruism $(r=.14, p<.05)$ and students' sportsmanship $(r=.16, p<.01)$. 
Hierarchical Multiple Regression

Table 9

Hierarchical Multiple Regression Predicting Academic Achievement - GPA

\begin{tabular}{lccc}
\hline Independent variables & \multicolumn{2}{c}{ Academic Achievement (Grade Point Average) } \\
Step 1 & Step 2 & Step 3
\end{tabular}

\begin{tabular}{|c|c|c|c|c|}
\hline Self-efficacy & $.16^{*}$ & $.15^{*}$ & & $.16^{*}$ \\
\hline Intrinsic motivation & $.17^{* *}$ & $.17^{* *}$ & & $.16^{*}$ \\
\hline Extrinsic motivation & .10 & .10 & & .06 \\
\hline Lecturers' OCB & & & .10 & \\
\hline Students' Courtesy/Altruism & - & - & & $.14^{*}$ \\
\hline Students' Civic Virtue & - & - & & .09 \\
\hline Students' Sportsmanship & - & - & & $.12 *$ \\
\hline
\end{tabular}

$\begin{array}{llll}\overline{\mathrm{R}} 2 & .06 & .06 & .09 \\ \Delta \mathrm{R} 2 & .05^{* *} & .00 & .03^{* *}\end{array}$

${ }^{*} p<.05 ;{ }^{* *} p<.01$

The results of the hierarchical regression (Table 9) analysis show that academic achievement measured based on Grade Point Average (GPA) has a significant relationship with 4 variables ( $9 \%$ explained variance). In the full model, the four variables that were positively related in decreasing order: Self efficacy $(\beta=.16, p<.05)$, intrinsic motivation $(\beta=.16, p<.05)$, students 'courtesy / altruism $(\beta=.14, p<.05)$ and students' sportsmanship $(\beta=.12, p<.05)$. Both, selfefficacy and intrinsic motivation entered at Step 1 explained 6\% of the variance in GPA. Additionally, students' courtesy / altruism and sportsmanship entered at Step 3 explained 3\% of the variance in GPA. Unexpectedly, lecturers' OCB entered at Step 2, was found not to be a significant predictor of GPA.

\section{Discussions}

Academic excellence is one of the areas of research that continues to get the attention of researchers who continuously investigate contributing factors at primary, secondary and tertiary education. Among the variables that are beginning to gain the attention of researchers as a contributor to academic excellence is OCB. Although the first study examining the impact of OCB on academic performance was conducted almost 10 years ago by Allison et al., (2001), further studies attempting to expand the relationship between OCB and academic achievement are relatively slow. Only a few studies attempted to examine the extent to which $O C B$ is able to contribute to academic performance. Studies that examine the impact of OCB on academic performance take one of two approaches, namely the lecturers' OCB or the students' OCB. There have been no studies examining the impact of both OCBs on academic performance, simultaneously. This study was designed to examine the effect of both, lecturers' $O C B$ and students' $O C B$ on academic performance among diploma and bachelor students in Malaysia. In this study, we have also controlled some of the variables previously associated with academic achievement, namely self-efficacy and motivation. 
Descriptive statistics of this study generally indicate that the lecturers have high OCB levels. For students, although the mean value is more than mid-point 3 , it is not too high compared to lecturers. The results of this study that shows self-efficacy and intrinsic motivation contribute to academic performance have strengthened the argument of the importance of these two variables in explaining the academic success of students. The results of this study are in line with some previous studies (e.g., Vansteenkiste et al., 2004; Choi, 2005). However, the results of studies that lecturers' OCB was not contributed to academic performance is something that is unexpected. We believe that this study failed to obtain evidence of the relationship between lecturers 'OCB and students' academic performance is likely due to the online learning environment that stems from the transmission of Covid-19 since early 2020. Lecturers not only need to familiarize themselves with online teaching but also need to modify teaching materials, assessment methods, take the necessary steps to motivate students and so on. Some constraints faced by students studying online include the absence of devices, especially laptops and printers faced by some students as well as lack of data and internet connection and isolation. Students who study online at home also need to help parents with household chores which increase their workload. With such atmosphere, it is believed that students expect more assistance and consideration from the lecturers compared to the faceto-face learning environment they are familiar with. It is possible that the measurements of lecturers' OCB developed specifically for conventional learning are less suitable for online learning and therefore do not contribute to students' academic performance.

The results of the study which showed the two dimensions of the students' OCB, namely the combined items of courtesy and altruism as well as sportsmanship contribute to the GPA, is something that is relieving. At the very least, this study can provide additional evidence that students' OCB also actually plays a role in contributing to the student's own performance, which is in line with cognitive consistency theory. Students who naturally tend to behave positively such as looking at things or problems from a positive angle and do not find fault with anyone when faced with any situation (sportsmanship) and maintain relationships with friends and staff (courtesy) and ready to help -others (altruism) are seen to be more successful in terms of academic achievement. This study is not free from shortcomings. The used of a convenience sampling method, a moderate sample size, as well as measurement that is completely dependent on self-report are among the disadvantages of this study. This study should be seen as a study exploring the benefits of OCB for online learning systems. More research is needed to review the usefulness of OCB either on the part of lecturers or students for online study methods. Since the OCB measurements developed previously are for face-toface conventional learning systems, future studies are also desirable to try to develop OCB measurements specifically for online learning systems. Future studies should also examine the possibility of the relationship between $O C B$ and academic performance through certain variables as mediators.

\section{Conclusion}

The features of students' OCB, namely courtesy/ altruism, and sportsmanship as well as selfefficacy and intrinsic motivation, are significantly and positively influenced students' academic achievement. These are consistent with those of previous studies. The results of this study are able to provide implications in terms of action plans aimed at improving the academic achievement. The results of our study suggest that interventions to improve and encourage citizenship behaviors among students, as well as strengthening learning 
motivation and self-efficacy have the potential to improve students' academic achievement. However, the efforts carried out must be continuous as the change in behavior and attitude takes time but is something worthwhile. It is suggested that administrators of higher learning institutions, particularly lecturers, focus on these variables in improving students' academic performance. Training can be designed and delivered to enhance students' intrinsic motivation. The training content can focus on educating students on the importance of maintaining high academic excellence, as well as the worth and significance of all the courses that students must take in their studies. This will likely increase the intrinsic motivation of students. Training should also be used to strengthen students' skills and abilities so that they are more confident in achieving academic excellence. To demonstrate the importance of students' $O C B$, academic administrators and lecturers should be role models by exhibiting high levels of OCBs. The application of positive behaviors and attitudes through role models among educators as well as through specially designed exercises aimed at increasing selfconfidence and motivation is something that should be taken seriously.

\section{References}

Allen, T. D., \& Rush, M. C. (1998). The effects of organizational citizenship behavior on performance judgments: A field study and a laboratory experiment. Journal of Applied Psychology, 83(2), 247-260. https://doi.org/10.1037/0021-9010.83.2.247

Allison, B. J., Voss, R. S., \& Dryer, S. (2001). Student classroom and career success: The role of organizational citizenship behaviour. Journal of Education for Business, 76 (5), 282-289.

Angus, D. (2004). Understanding academic performance and progression of first-year accounting and business economics undergraduates: the role of approaches to learning and prior academic achievement. Accounting Education, 13 (4), 409-430.

Bandura, A. (1997). Self-Efficacy: The exercise of control. New York: Freeman.

Bruinsma, M. (2004). Motivation, cognitive processing and achievement in higher education. Learning and Instruction, 14(6), 549-

568. https://doi.org/10.1016/j.learninstruc.2004.09.001

Burns, W.R.T., \& DiPaola, M.F. (2013). A study of organizational justice, organizational citizenship behaviour and student achievement in high schools. American Secondary Education, 42(1), 4-23.

Chen, X. P., Hui, C., \& Sego, D. J. (1998). The role of organizational citizenship behavior in turnover: conceptualization and preliminary tests of key hypotheses. Journal of Applied Psychology, 83, 6, 922- 931.

Choi, N., (2005). Self-efficacy and self-concept as predictors of college students' academic performance. Psychology in the Schools, 42 (2), 197-205.

Cooper, D. R., \& Schindler, P.S. (2001). Business Research Methods. McGraw-Hill Higher Education, London.

Danilowicz-Gosele, K., Lerche, K., Meya, J., \& Schwager, R. (2017). Determinants of students' success at university. Education Economics, 25(5), 513-532. http://doi.org/10.1080/09645292.2017.1305329

Deci, E. L., \& Ryan, R. M. (1985). Intrinsic Motivation and Determination in Human Behavior. Plenium, New York.

DiPaola, M. F., \& Hoy, W. K. (2005). School characteristics that foster organizational citizenship behaviour. Journal of School Leadership, 15, 387-406.

DiPaola, M., \& Tschannen-Moran, M. (2001). Organizational citizenship behaviour in schools and its relationship to school climate. Journal of School Leadership, 11(5), 424-447. 
Festinger, L. (1957). A theory of cognitive dissonance. Stanford University Press.

Gouldner, A.W. (1960). The norm of reciprocity: A preliminary statement. American Sociological Review, 25(2), 161-178.

Gravetter, F. J., \& Forzano, L. A. B. (2009). Research methods for the behavioral sciences. Belmont, CA: Wadsworth Cenage Learning.

Hair, J., Anderson, R., Tatham, R., \& Black, W. (1998). Multivariate data analysis. 5th Edition, Prentice Hall, New Jersey.

Hong, S. (1984). The age factor in the prediction of tertiary academic success. Higher Education Research and Development, 3(1), 61-70. Doi:10.1080/0729436840030105.

Hsieh, T. L. (2014). Motivation matters? The relationship among different types of learning motivation, engagement behaviors and learning outcomes of undergraduate students in Taiwan. High Education, 68, 417-433.

Khalid, S. A., Jusoff, K., Othman, M., Ismail, M., \& Abdul Rahman, N. (2010). Organizational citizenship behaviour as a predictor of student academic achievement. InternationalJournal of Economic and Finance, 2(1), 65-71.

Krejcie, R. V., \& Morgan, D. W. (1970). Determining Sample Size for Research Activities. Educational and Psychological Measurement, 30, 607-610. https://doi.org/10.1177/001316447003000308

Li, S., Xu, Q., \& Xia, R. (2020). Relationship between SES and academic achievement of junior high school students in China: The mediating effect of self-concept. Frontiers in Psychology, 10, 1-7. https://doi.3389/fpsyg.2019.02513

Organ, D.W. (1990). The motivational basis of organizational citizenship behaviour. Research in Organizational Behavior, 12, 43-72.

Organ, D.W. (1988). Organizational citizenship behaviour. Lexington, MA: D.C. Health.

Organ, D.W. (1997). Organizational citizenship behaviour: It's construct clean-up time. Human Performance, 10, 85-97.

Podsakoff, P. M., Ahearne, M., \& MacKenzie, S. B. (1997). Organizational citizenship behaviour and the quantity and quality of work group performance. Journal of Applied Psychology, 82(2), 262-270. https://doi.org/10.1037/0021-9010.82.2.262

Podsakoff, P. M., Mackenzie, S. B., \& Paine, J. B. (2000). Organizational citizenship behaviours: A critical review of the theoretical and empirical literature and suggestions for future research. Journal of Management, 26, 513-563

MacKenzie, S. B., Podsakoff, P. M., \& Fetter, R. (1993). The impact of organizational citizenship behaviour on evaluations of salesperson performance. Journal of Marketing, 57(1), 70-80.

Mazen, A., Herman, S., \& Ornstein, S. (2008). Professor delight: Cultivating organizational citizenship behavior. Journal of Management Education, 32(5), 563-574.

Nunnally J. C. (1978) An Overview of Psychological Measurement. In: Wolman B.B. (eds) Clinical Diagnosis of Mental Disorders. Springer, Boston, MA. https://doi.org/10.1007/978-1-4684-2490-4.

Perger, M., \& Takacs, I. (2016). Factors contributing to students' academic achievement success based on the students' opinion at BME Faculty of Economic and Social Sciences. Periodica Polytechnica Social and Management Sciences, 24(2), 119-135. Doi:10.3311/PPso.8843

Perna, L.W., Thomas, S. L. (2008). Theoretical perspectives on student success: Understanding the contributions of the disciplines. ASHE Higher Education Report, 34(1), 1-87. 
Podsakoff, P. M., \& MacKenzie, S. B. (1994). Organizational citizenship behaviours and sales unit effectiveness. Journal of Marketing Research, 3, 351-363

Robert, W. (2013). Relevance of prior academic qualifications to predicting the academic achievement of undergraduate students: An analysis of law enrollees at Makerere University. Journal of College Teaching \& Learning, 10(2), 143-

Robbins, S. B., Lauver, K., Le, H., Davis, D., Langley, R., \& Carlstrom, A. (2004). Do Psychosocial and Study Skill Factors Predict College Outcomes? A Meta- Analysis. Psychological Bulletin, 130(2), 261-288. https://doi.org/10.1037/0033-2909.130.2.261

Roebken, H. (2007). The Influence of Goal Orientation on Student Satisfaction, Academic Engagement and Achievement, Electronic Journal of Research in Educational Psychology, 5(3), 679-704.

Schroeder, M. (1990). Diagnosing and dealing with multicollinearity. Western Journal of Nursing Research, 12(2), 175-184.

Schroeder, S. (2011). Student success in higher education. Executive summary. AFT Higher Education. (Online). Available from:

http://www.aft.org/pdfs/highered/studentsuccess0311.pdf(Accessed: January2021).

Sekaran, U., \& Bougie, R. (2010). Research methods for business: A skill building approach. (5th ed.). John Wiley \& Sons.

Sikhwari, T.D. (2014). A study of the relationship between motivation, self concept and academic achievement of students at a university in Limpopo Province, South Africa. International Journal of Educational Science, 6(1), 19-25.

Spreitzer, G. M. (1995). Psychological empowerment in the workplace: dimensions, measurement, and validation. Academy of Management Journal, 38(5), 1442-1465.

Vansteenkiste, M., Simons, J., Lens, W., Sheldon, K. M., \& Deci, E. L. (2004). Motivating Learning, Performance, and Persistence: The Synergistic Effects of Intrinsic Goal Contents and Autonomy-Supportive Contexts. Journal of Personality and Social Psychology, 87(2), 246-260. https://doi.org/10.1037/0022-3514.87.2.246

Williams, L. J., \& Anderson, S. E. (1991). Job Satisfaction and Organizational Commitment as Predictors of Organizational Citizenship and In-Role Behaviors. Journal of Management, 91, 601-617.

York, T., Gibson, C., \& Rankin, S. (2015). Defining and measuring academic success. Practical Assessment, Research and Evaluation, 20(5), 1-20.

Zhu, Y. Q., Chen, L. Y., Chen, H. G., \& Chern, C. C. (2011), How does internet information seeking help academic performance? The moderating and mediating roles of academic self-efficacy. Computers \& Education, 57 (4), 2476-2484.

Zimmerman, B. J. (2000). Self-efficacy: an essential motive to learn. Contemporary Educational Psychology, 25 (1), 82-91. 